\title{
2
}

\section{CROSS-CHANNEL AFFECTIONS}

\section{Pressure and persuasion in letters to Calvinist refugees in England, 1569-1570}

\author{
Susan Broomhall \\ THE UNIVERSITY OF WESTERN AUSTRALIA
}

On Sunday 26 February 1570 (NS), Henry Fléel and his ten-year-old companion Jehan Desmadry were stopped by the Captain of the Fort and Château of Hénuin (now Hénin-Beaumont, in the department of Pas-de-Calais, to the east of Lens) in a small boat as they were making their way to Calais. Despite Fléel's initial claims that he was simply a poor man from Laventie seeking to earn his living in the fields near Marck, it was soon discovered that his basket filled with cheese, jams and onions contained a false bottom with an additional compartment holding seventy-nine letters addressed to family and friends in England. Fléel confessed that he had been asked to deliver these letters to a certain Donnèrque Olay at the Three Kings tavern in Calais. Fléel claimed that he did not know any of the authors of the letters, which had been given to him by a certain du Buis between Hondschoote (in present-day France) and Reningelst (today, in Belgium). Fléel declared he was neither a Lutheran nor an Anabaptist but admitted that he no longer attended mass and recognized only two sacraments: baptism and communion. Although Fléel's fate is not known for certain, his case was transferred to the Council of Troubles (1567-1574), a special tribunal designed to investigate those involved in the religious and political turmoil within the Habsburg Netherlands. In its files, he was named as one of 'two obstinate heretics', a term that often ended with a death sentence and thus boded ill for the carrier of the clandestine letters. ${ }^{1}$

This chapter concerns the textual and social experiences of a group of people who were excluded from practice of their faith where they lived, communicating with others who had decided to go, into or had been forced, into exile from their homes and loved ones. Their letters, written in French and Flemish by both men and women, employ an explicit emotional vocabulary to describe their traumatic experiences as individuals in dire need and to express their identity as members, despite separation across the space of the Channel, of 
a shared confessional community. They did so in many cases in order to place pressure on those already abroad to assist them. As such, they offer a rare resource to analyse the gendered and emotional experiences of Calvinist persecution, and insights into both expectations and experiences of exile in the later sixteenth century. Through them, we see the heavy practical and emotional expectations placed on friends and family who had become part of the Calvinist diaspora abroad.

The stranger communities of early modern England have been the focus of analyses of their integration, religious beliefs, working practices, and cultural, religious, and economic impact within England. ${ }^{2}$ More recently, scholars have analysed the relationships that French-speaking refugees forged on their arrival in London. The fledgling sixteenth-century French community at Threadneedle Street in London looked to support its members financially, socially, and emotionally in its initial formation, as parishioners and elders tried to manage the provision of charity and social relations internally, across the Channel, and with the wider London population. These were challenging and complex issues, and the documentary sources of the Church express frustrations, anger, and fears, both of the elders who expected parishioners to conform to particular moral, sexual and social behaviours, and of those who did not accept the Church's capacity to regulate their lives in such ways. ${ }^{3}$ But what of those who did not or could not flee persecution, or live where they could practise their faith freely? What of those who remained behind in their homelands? What were their hopes and fears? How did they experience dislocation from families and friends and the disintegration of communities now living apart?

This chapter explores how these letters, as objects and texts, produced social identities and constituted feelings. As performativity, gender, and new materialist scholars have argued, humans and objects are co-constitutive and socio-material assemblages; that is, specific combinations of people, things, and places in time are ontologically productive. ${ }^{4} \mathrm{I}$ argue that these letters, by virtue of their nature as material objects embodying both communicative practices and textual content, created feelings and identities for those in the geographically dispersed network through which they passed. Their productions of selves and emotions were intertwined. Emotional displays were not only informed by pre-existing social identities but were dynamic components in the creation and articulation of forms of selfhood appropriate to specific contexts. ${ }^{5}$ As such, the letters were emotional and social transactions that managed sentiments and fostered intimacy, and a socio-material assemblage that situated far-flung individuals within a common faith community.

\section{Materialising family and faith communities}

These letters were the product of covert communicative practices among a marginalized Calvinist community that extended, in this case, from the southern Netherlands and northern France to England. The location of the authors 
who indicated where they were writing included towns in relatively close proximity: Valenciennes, Tournai, Lannoy, Nieuwkerke, Armentières, and Ypres. While the author's location was rarely stated, most of the letters were dated and show that they had been written between November 1569 and mid-February 1570. Dates were important when the ability to correspond was so irregular and uncertain. Additionally, only two letters were not signed. Did this perhaps attest to the authors' belief in the security of a secretive communication network? Certainly, the act of writing and of signing one's name carried very real dangers to the authors who risked their lives to create this correspondence. Indeed, some indicated that they had destroyed previous correspondence they had received for safety. A letter by Caterienne Glouquette to her husband Nicolas Herman indicated how the letter he had sent a year ago had been 'received by little Nicolas, and sent on to his wife and after she had had it a good five weeks, she burned it'. 6

These letters were all intended to be transmitted across the Channel, and in some cases were addressed to towns where recipients were expected to be found, such as Norwich and London. All carry the name of the intended recipient on the back of the letter or on the cord tying the papers together. A number were addressed to third parties, who were, it seems, presumed to know the whereabouts of the intended recipients: 'To be given to Martin du Val, a young man living in London in the house of the son of Terroeuvre'? The sister of Mary Orman asked that her letter 'be given to Jacque Gelle to pass on to Mary Orman, living in the town of London'. Others were addressed purely by name, implying (or perhaps hoping) that knowledge within the English migrant communities would be sufficient for the letter to find its owner. A niece sent her letter 'to my uncle, Pierre Gruelz, wherever he may be'. The letter of Magrite, the wife of Jan Lecoup, was labelled simply 'I am to Jan'; that is, 'I [the letter] am [to be sent] to Jan'. ${ }^{10}$

The authors may not have shared a common language. The majority wrote in French but other letters were in Flemish. However, the letters displayed evidence of strong community connections that enabled this communication practice. Some appeared to have been scribed by a third party on behalf of their senders. The investigation of documents of Fléel and his companion also reveal other elements of the network. Fléel explained that he had received the letters from du Buis and was intending to pass them on to Olay at the designated tavern in Calais. The barque in which they were stopped belonged to a Jehan Rouzée, who worked between Saint Omer and the port at Calais. The evidence of young Jehan Desmadry revealed that a woman whose name he did not know supplied the basket with the double bottom to Fléel and other unidentified women had brought cheeses to go in it. Desmadry himself was, rather like the letters, expected to find his father, who had taken refuge in England a year before from his home of Lille. ${ }^{11}$

Fléel claimed that he knew none of the letter writers personally, but what bound the group was their shared distance from Catholic beliefs. Fléel, for 
example, declared that 'he did not know what is to be a calvinist or papist'. His ambiguous responses on faith, lack of attendance at mass, and recognition of only two sacraments were sufficient to place him under investigation by authorities. ${ }^{12}$ The religious upbringing of his young companion, Desmadry, was equally ambiguous. Jehan had declared that his father had eaten eggs and meat on Fridays and Saturdays, but said that his mother, Marie de le Ruelle, continued to observe Catholic feast days and regularly attended mass. Her own letter to her husband included in the basket, however, suggested firmly Calvinist beliefs. ${ }^{13}$ From Desmadry's testimony and the letters themselves, the roles of other women and men in transcribing and transmitting the documents and preparing Fléel's basket were revealed. A far wider group of people with complex but nonconformist religious sympathies shared the risks to enable this epistolary communication pathway to function. As they moved through these networks that they helped create and maintain and through their content, these letters became active agents in the production of emotional and faith identities of these individuals, practices and objects.

The vast majority of the letter writers appeared to be relatives of the intended recipients - fathers, wives, siblings, most commonly, but also uncles, nieces, and nephews as well as in-laws. The relationship of a further group of authors to their recipients is less clearly identifiable although some appear to be business colleagues and friends. Thirty percent of authors were female, but only fifteen percent of the recipients were women. ${ }^{14}$ Some were men whom we know were banished in preceding years. In this sense, the letters provide a rare opportunity to see how religious persecution in the Low Countries was experienced and, to some extent, articulated by women who were not the usual political dissidents listed as banished or executed in the archives of the Council of Troubles.

A number of letters indicated that the authors were enclosing goods with their letters. Foodstuff and clothing were offered by wives and daughters to men who would once have been part of their household. Marinne's letter to her husband Parin enclosed two shirts for him. ${ }^{15}$ The daughter of Willame le Roy sent a pot of cream on behalf of her sister and asked her father to thank her sister Susaenne for sending needles. ${ }^{16}$ A number sent fabric, usually accompanied by discussions of business transactions. Alongside the seventy-nine letters discovered by the authorities were a series of items including 'two and a half ells of blue cloth; item, four shirts for a small boy; item two shirts of some little girl; item, three men's shirts; a bonnet; two gingerbreads, two cheese, pots of jam, two ells of white cloth', as well as money. ${ }^{17}$ These gifts were not all intended to sustain business relations. Some were meant to reinforce ties within families by demonstrable attendance to generally female household duties. These acts and objects were behaviours with strong emotional resonances, aimed at situating typically distant men within a series of familial affiliations and obligations to female relatives. 
Evidence of a broader set of sociabilities was also to be found in the content of the letters themselves. Many informed their recipients of not only personal and familial events and feelings, but also those of a wider community. Jan Bacler told his brother Eloy, 'Know that my sister Jacquelinne wishes to be remembered to Piere le Gay'. ${ }^{18}$ Frans Baeke wrote to Willem and Pieter van der Schoore and Frans de Berre, mentioning in closing that he had spoken to 'Daneel's wife who sends her greeting, Daneel is in Ypres, and Kalleken his sister was fine and Frans too'. ${ }^{19}$ Most letters delivered information from the wider community in which both authors and recipients were embedded. In reverse, a few made clear how the authors themselves learned of their relatives and friends abroad. The daughter of Willame le Roy revealed that she had heard 'from Jan Haudoux that Jacquet Rousel had told him' that her mother had died. ${ }^{20}$

Shared religious beliefs were explicitly articulated in most letters. Statements of faith frequently opened and sometimes closed the letters by both women and men, thus framing the entire correspondence within the context of shared religious beliefs. Many were brief: 'Praise be to God' or 'Greetings with Jesus Christ'. ${ }^{21}$ Jacob de Smit commenced his letter to Maertyne Godscalcs and his son Jan de Bus: 'Psalm 46: God is my refuge in the time of pressure'. ${ }^{22}$ Two included short prayers in Flemish. ${ }^{23}$ These expressions assumed authors and recipients were joined together in a shared community of faith. Victor Kirstelot went further in describing the 'brothers and sisters bidden to come together with Christ in all his glory as we hope to come into God's grace', and concluded his letter with his wishes not only to named individuals but 'to all brothers in the Lord'. ${ }^{24}$

Only a few, however, made longer religious statements connected directly to their own experiences or those of their recipients. These articulations were often messages of comfort in the context of addressing difficult topics likely to upset their readers. Marie Lengilon announced the death of her husband's mother to him, assuring him that

the Lord God called your mother and took her from this vale of misery, and one must not be upset about what pleased the Lord, for, as we say every day, his will be done. And since it is his will, we must not complain. She is very happy, for we have only pain in this valley of misery and when the Lord God calls us close to him and we are drawn from this vale of misery, we can be at peace. ${ }^{25}$

Resignation to God's will was paramount, affective expression consistent with contemporary Calvinism. ${ }^{26}$ The brother of Jehan de Denain asked the latter to resign himself to his fate of being an exile by comparing his sufferings to those of the apostle Peter. ${ }^{27}$ Jan Bacler explained to his brother that their cousin Paul asked to be remembered and recommended he practise patience in his affliction, for nothing else was promised 'to true Christians in this world'. ${ }^{28}$ Few were 
explicitly celebratory in tone, as was Philippe Caulier, writing to his friend Jacques De Le Haie, who expressed his gratitude to God that he was able to live in peace thus:

And praise be to God, until now he has given us food and despite our enemies, has let us rest in grassy fields and walk alongside running waters, for we have hope that at the end of our days we will enjoy salvation, gained for us by Jesus Christ. ${ }^{29}$

In the context of the challenging feelings that distress, death, and distance provoked for both authors and recipients, these expressions were articulations of faith that aligned, shared, and assuaged. These epistolary articulations were thus both emotional responses to their experiences and aimed at affective connection and support to others. They were emotional performances that were key to individuals' socialization within this faith community.

In their material and textual aspects, these letters and the communication practice in which they were embedded were part of complex, ongoing interactions and engagements between individuals. As the communication network was practised through these articulations, and as the letters were prepared, scribed, and carried, they fostered connection, cohesion and intense feeling among members who were tied together as a close-knit, albeit far-flung, community. These documents were not simply products of a network with faith, social, and emotional dimensions; they were active agents in shaping and sustaining that community and transcending the geographical distance between its members.

\section{Feelings in circulation}

The letters were written, it seems, because an opportunity had arisen for them to be carried to loved ones abroad. About a third concluded with some statement that they were written 'in haste', 'in very great haste' or 'because the messenger is hurrying. ${ }^{30}$ What were the most important things for authors to communicate in such a context and in this form? While the letters varied in length and detail, they followed a common pattern, expressing good wishes for the health of the recipient, then documenting the health of those around them. Many noted letters they had received or sent, while others lamented a lack of communication from the recipient. Discussion of family affairs ranged from instructions on children's education, queries about marriage arrangements and dowry sums to pregnancies, births, deaths, and marriages among wider kin. Family affairs provoked the expression of mixed emotions in senders, celebrating the joy of a newborn child or the development of a toddler, grieving the loss of loved ones, particularly when they had died without the presence of the recipient, frustration sometimes at the lack of support from a husband or father, but also sorrow at the long parting and lack of knowledge about family members 
over the ocean. They employed an explicit emotional vocabulary that was purposeful to their objectives. It reflected gendered power dynamics between authors and recipients but also aimed to enact and shape feelings and actions between individuals.

Authors of both sexes expressed a strong sense of loss and longing for their loved ones, generally as members of the immediate family unit: mothers, fathers, wives, brothers, and sisters. The mother of Benoy de le Court emphasized grief at his absence, 'for which I cry many times a week', and her fears: 'now I have no one and it seems that I will never see you again, nor my two daughters, nor your children'. ${ }^{31}$ Isabeau Parent told her husband: 'I would like to be there for I promise you that my body is here but my heart is with you very often'. 32 If he had received the letter, Martin du Val would have learned that:

as to your father and mother, they pray most affectionately that you write back home some news as soon as possible, for, because they have had no news of you, it seems to them that you are dead, even though all they desire is to be given news of you to know of your state and how it is for you, in doing so you will give them joy and jubilation. ${ }^{33}$

Marie Lengilon wrote to her husband, that although

it has pleased God that we be far away from one another, he does not make us forget one another in our hearts... not a day goes by when my heart does not weep. I pray God that he gives you great patience. ${ }^{34}$

These authors grieved at the loss of family and friends who were far from them in the very documents in which they were also enacting and maintaining these networks and reducing the emotional distance between them. ${ }^{35}$

Significantly, the articulation of feelings claimed to be experienced by women was foremost in these letters. Thomas Le Den wrote to his sister Jenne of their mother's desire for her daughter to return, 'for since the hour and day that you went, her eye has never been dry and she is always crying, praying to God who watches over you to return you to her and us all'. ${ }^{36}$ The wife of Martin Plennart told him: 'your daughters Annette and Marie keep asking when their father will come, your daughter Marie says that you cannot come because you have sore feet'. ${ }^{37}$ Authors who reported on the feelings of others, usually of women and children, perceived, it seems, that these lamentations and sorrow of the vulnerable would be most effective in achieving the aims they sought.

Not only women's sadness and grief filled the pages of these letters. The letters of wives and sisters could also express frustrations and even anger, insofar as these feelings stemmed from a lack of communication with their loved ones. Hennette wrote to her husband Antoine Renier, 'I am most surprised how you did not write a letter back sooner than to write on the back of the letters of Jan 
Desmadry'. ${ }^{38}$ Chatelinne Boudiffart's letter to her brother Jan contained a complaint that she had not heard from their cousin:

I am most stunned that I have no news of him; there are several who manage it; it seems to me that if he wanted to write back, he would have been able to send a letter, if it pleased him. ${ }^{39}$

In a similar vein was the letter from Jacqueline Leurent to her husband Jehan Dambryne:

I am completely amazed that two years have passed and I have no news of you, I marvel at it, I do not know if you do not write to me because you are mad at me or not. If it has suited you to leave me, that was not my doing and I am most mad about it. I am in great pain at night, to have had no news of you, even though I have written to you several times. ${ }^{40}$

Women expressed not only surprise but hurt and anger at men's apparent silence and, as the latter two letters show, they represented the absence as a considered personal slight that reflected these individuals' feelings for them.

Frustrations were apparent in some men's letters but in a different way. A lack of information on how to proceed in business dealings provoked Pierre Taiart to comment to his friend Hernoul de le Rue:

This letter will serve to let you know that I am most surprised that I have had no news of you, for I sent you several letters in the last four months. And I have no response from you, I do not think that you would be so ungrateful as to not write at all. So I beg you to do everything in your power to send me the money that you owe me from the merchandise that I sold you and delivered to my brother and to you. ${ }^{41}$

These were clearly matters of some feeling for Taiart, but his letter focussed on the specific practical objectives and funds desired from de le Rue rather than consideration of what the deficit might indicate about their personal relationship.

The specific language of feelings that were explicitly referenced in these letters was gender-specific. It was primarily women's emotional experience that was discussed, whether by themselves or by others. Furthermore, these were often dramatic and forceful expressions about feelings that were designed to move their readers. With such limited means of communication, these emotional performances were intended to be effective in producing the results to which authors aspired. They were combined, most commonly in the letters of or about mothers, daughters, or wives, with lamentations concerning their impoverished circumstances and pleading for help of some kind. One letter to a husband reported that 'this is to let you know that Marinne has no income, because the 
king expects that wives will go to their husbands, and so His Majesty confiscates all their goods'. ${ }^{42}$ Marinne enclosed shirts for her husband, perhaps indicating her willingness to fulfil her wifely duties towards him in turn.

The letters were carefully crafted for maximum emotional effect. Chatelinne Boudiffart wrote to inform her brother Jan that her husband had died, and asked him to pray to God 'that I can be both a good father and good mother to my four children'. ${ }^{43}$ Likewise, the niece of Pierre Gruelz announced the sudden death of her mother, and her father's decision to remarry, taking all that remained to his new marriage. She described her siblings' status as 'now seven poor children, without a mother', hoping for Gruelz's support. The letter closed with a reminder of her uncle's obligations to a niece and 'my sister Katelin without a mother'. ${ }^{44}$ In such ways, women's strong emotional and repeated reinforcement of their difficult circumstances seem designed to apply pressure on their relatives. They emphasize male responsibilities to them and their own expectations of assistance.

Some women were blunt in their need for support, which they constructed as both financial and emotional. Barbe Detelus insisted to her husband Louy du Bois: 'I would like you to reside in a town where we could come with you. I have great trouble earning my living; I have assistance from no one' ${ }^{45}$ The letter of Jenne Géguenter combined a request for advice on how to raise funds, with a plea for direct financial assistance from her recipient. She explained to Jacque Coutrerie le jeune, her brother: 'I will not have the money that you spoke of ... I have a great shortage, and right now, I have no means to earn my living', 'I do not know how to cover my costs and pray you send it to me as soon as you can'. ${ }^{46}$ Some women were not afraid to express their anger, as did the widow Jonneviel to Nicaise Frappes, about a debt between them:

I never received from you any response, it's like a joke, Nicaise, for you can well imagine that I do not have the thousand écus... You are the cause that my daughter refused several good marriages, for if a good husband came along, even a prince, it would not be possible for her to marry him, for the custom is such that one does not ask for girls for their knowledge but for their money. ${ }^{47}$

Although the financial challenges that women faced were rarely expressed in such ardent terms, their supplications were embedded within a rich emotional discourse of marital, familial, and occasionally social obligations designed to be persuasive to male recipients.

Such strategies were by no means unique to these letters. Both Catholic and Protestant relief bureaux regularly supported women in need, who were seen as less able to support themselves, particularly without male assistance. This was consistent with the charitable practice of the very Calvinist communities in England to which these letter recipients were contributors. The specific difficulties of families left behind across the Channel was a particular concern for the elders 
at the Threadneedle Street French Huguenot community at this period, for example, and they provided funds to support communities in difficulty abroad and recommended the reunification of families in one location as soon as possible. $^{48}$

By contrast, fathers provided instruction to sons about finances, education, and good living. Paternal admonition in one letter came with advice for a son Arnoult on the education of the author's grandson: 'I beg you to hold the hand of your son Jehan, have him taught Latin, to write numbers well and then afterwards to put him to learning languages, for he is ready, make sure he does not waste his time'. ${ }^{49}$ Creton gave firm advice regarding his son's conduct before God, to never abandon the Temple and to keep away from bad company. Money 'earned through hard work should never be uselessly dissipated', he added. ${ }^{50}$ Where women rendered service through sending items of clothing and food, father figures expressed care for their recipients through the provisions of finance and discussion of moral and educational expectations. Philip Grace has recently conceptualized the late medieval paternal role as one of 'affectionate authority', in which their powers were safeguarded by responsibilities of care for their charges, in multifaceted relationships demonstrated through repeated performance. ${ }^{51}$ The ability of paternal and other authority figures to exert control over family members or broader faith communities was, however, severely challenged in practice by situations such as exile. Yet letters, alongside more traditional instruments such as the consistory, formed part of a wide network of surveillance and information that aimed to enable men in the Huguenot hierarchy in England to both discipline and support community members. ${ }^{52}$

Both men and women used emotive language to re-balance familial and social power dynamics in their favour, often leveraging familial identities to remind relatives and friends of their duties. Gender as well as family roles and hierarchies shaped both emotional expression and the expectations of how recipients should respond. The letters of women typically employed more explicit and forceful emotional language and more commonly articulated 'negative' emotions such as grief, sorrow, anxiety, and anger. Their letters also more frequently connected recipients' failure to act or respond to authors' own feelings and sense of worth rather than possible difficulties in recipients' lives. This was a strategic deployment of ideas about authors' personal value to recipients, likely designed to oblige the latter to demonstrate their care for these women. By contrast, the letters of male authors tended to speak more concretely of events, financial transactions, and business matters, and were more emotionally indirect, even to the point of articulating the feelings of women around them rather than whatever they might have felt themselves. Yet, in their different ways, all these letters were emotive, in the sense that their choice of words, tone, and topics of discussion aimed to evoke particular feelings in the recipient that would achieve their objectives. 


\section{The experience of exclusion}

The practical and emotional weight of not participating in Catholic faith culture was palpable in many ways in the letters. Two mentioned the presence of Spanish soldiers in Tournai, who had been billeted in homes. The brother of Jehan de Denain described how 'we are tormented by Spanish soldiers' who had to be provided with linen and candles and the right to sit at the master's fire in lodgings. ${ }^{53}$ Marie de le Ruelle, the mother of little Jehan who accompanied Henri Fléel, indicated that, in Lille, she had been obliged to take in four Spaniards despite the confiscation of her goods. ${ }^{54}$ Gillis vanden Keere noted the rising cost of living and the expenses of timber, butter, and meat. ${ }^{55}$ The downturn in the textile trades was sketched by a number of authors who were not able to fulfil obligations to recipients. In these letters, wives, brothers, or business colleagues often justified their inability to assist in a requested transaction by their lack of funds or capacity to do so.

A number of authors mentioned loss of goods and properties and the hardships they had endured. Elizabet Lot told her husband: 'we do not know how to receive anything, we suffer so much and others as well. So much so that we cannot help each other, and we are not the only ones in danger' ${ }^{56}$ The departure of those who had been targeted could end in the confiscation of their goods. Magrite explained to her husband that she did not want to sell anything, 'for if I sell, the King would want to take it'. ${ }^{57}$ Philippe Caulier signalled the persecution of Calvinists obliquely to his friend Jacques De Le Haie: 'to write to you again of the ravishments, the pillaging, and the danger would take a long time'. ${ }^{8}$ Marinne mentioned the execution of a co-religionist in the briefest of terms to her husband: 'As for Lambert, he died by the sword' 59 Others, though, prayed for better times. The father of Arnoult wrote to his son of his hopes that "with time the princes will find agreement together so that people can live in peace. We pray to God that he puts them in agreement'. ${ }^{60}$ Gillis vanden Keere judged the repression was lessening except for 'one here and there' caught 'listening to sermons and being from a consistory'. ${ }^{61}$ The father of Thomas le Oustfriet told him to 'take courage, it will all change for the better, if it pleases God'. ${ }^{62}$ Generally, letter-writers used their opportunity to communicate positive messages of hope and, in the meantime, acceptance of God's will.

While some authors instructed their recipients to stay put, many others expressed their desire for loved ones to come home and judged the situation to be improving. Jacque Desrumaulx, for example, visualized the day of his brother's return: 'We would be most joyous, if you returned ... for the country is at peace at the moment, if you wanted to return to visit or stay, you would be very welcome'. ${ }^{63}$ The wife of Martin Plennart begged him:

not be melancholy for, at present, nothing is said in Valenciennes... it is true that they confiscated the goods of some who were banished but there 
is no word about it at the moment. My desire is that you be near your wife and your children, for you would be as safe as the others who are coming back every day now. ${ }^{64}$

A father recommended to his son Pierre that he should 'return here, there is nothing to fear for things are not in such upheaval as you have heard ... you would be in as much safety here as where you are at present'. He even gave advice how to do so via Calais, on a Saturday, by boat with others returning from the market. ${ }^{65}$ Isabeau Parent told her husband that she was 'most annoyed that he had been so long from the country, there are others that you know well, who are like us, and who are not so far apart'. ${ }^{66}$ Clearly, many imagined, or hoped at least, that the escape or migration of their loved ones was temporary and that they would one day be able to practise their faith where they lived. Few authors wrote of what they imagined those in exile were experiencing. They largely articulated their own feelings and assumed that their desire for reunion and return to homelands was shared.

\section{Conclusions}

Exclusion operated in spiritual and spatial terms for writers and their recipients respectively. Excluded from practice of their faith where they lived, individuals took to letters to lessen their geographical, faith, and emotional distance from others who were excluded from their homelands, families, and friends. This analysis suggests the intense pressure on these documents to do emotion work, transcend distance, and sustain community in the absence of alternative forms of contact among many of the authors and their recipients. As objects and as texts, these letters created strong sentiments. They materialized the powerful feelings of their authors, who put their lives at risk in composing and signing their missives. Letters attested to, and indeed made, community for these individuals, not only as letter-writers and recipients but also as scribes, deliverers, and others who put themselves in danger to carry the letters. It seems probable that Fléel died for his part in their transmission. Furthermore, the marginality of this community both at home and abroad intensified emotional relations among its members. The selves that these documents could articulate emerged through explicit and gender-specific emotional expression to describe distressing experiences of individuals in dire need-authors who had been left behind in homelands and who placed high expectations on refugees and migrants to support them practically and emotionally.

\section{Notes}

1 'deux hérétiques obstinez', Order to the Secretary of the Council, Brussels, [after 16 April 1570], Conseil d'État et Audience, $1177^{18}$, Archives générales du royaume à Bruxelles (hereafter AGR). Reproduced in A.L.E. Verheyden, "Une correspondance inédite adressée par des familles protestantes des Pays-Bas à leurs coreligionaires 
d'Angleterre (11 novembre 1569-25 février 1570)," Bulletin de la Commission royale d'histoire 120 (1955): 231. All dates have been adjusted to new style.

2 Key literature includes Andrew Pettegree, Foreign Protestant Communities in SixteenthCentury London (Oxford: Oxford University Press, 1986); Ole Peter Grell, Dutch Calvinists in Early Stuart London: The Dutch Church in Austin Friars, 1603-1642 (Leiden: Brill, 1989); Marcel F. Backhouse, The Flemish and Walloon Communities at Sandwich During the Reign of Elizabeth I (1561-1603) (Brussels: Koninklijke Academie voor Wetenschappen, Letteren en Schone Kunsten, 1995); Randolph Vigne and Graham C. Gibbs, eds, The Strangers' Progress: Integration and Disintegration of the Huguenot and Walloon Refugee Community, 1567-1889: Essays in Memory of Irene Scouloudi (London: Huguenot Society, 1995); Ole Peter Grell, Calvinist Exiles in Tudor and Stuart England (Aldershot: Ashgate, 1996); Andrew Spicer, The French-Speaking Reformed Community and Their Church in Southampton, 1567-c.1620 (London: Huguenot Society, 1997); Robin D. Gwynn, Huguenot Heritage: The History and Contribution of the Huguenots in Britain (1995; repr., Brighton: Sussex Academic Press repr., 2001); Nigel Goose and Liên Luu, eds, Immigrants in Tudor and Early Stuart England (Brighton: Sussex Academic Press, 2005).

3 Susan Broomhall, "Authority in the French Church in Later Sixteenth-Century London," in Authority, Gender and Emotions in Late Medieval and Early Modern England, ed. Susan Broomhall (Basingstoke: Palgrave, 2015), 131-49; Broomhall, "From France to England: Huguenot Charity in London," in Experiences of Charity, 1250-1650: Revisiting Religious Motivations in the Charitable Endeavour, ed. Anne M. Scott (Farnham: Ashgate, 2015), 191-212.

4 Karen Barad, "Posthuman Performativity: Towards an Understanding of How Matter Comes to Matter," Signs 28, no.3 (2003): 801-31; Bruno Latour, Reassembling the Social: An Introduction to Actor-Network Theory (Oxford: Oxford University Press, 2005); Daniel Miller, ed., Materiality (Durham, NC: Duke University Press, 2005); Diana Coole and Samantha Frost, eds, New Materialisms: Ontology, Agency, and Politics (Durham: Duke University Press, 2010); Jane Bennett, Vibrant Matter: A Political Ecology of Things (Durham, NC: Duke University Press, 2010).

5 I am drawing from insights developed by Judith Butler concerning the construction of gendered selves through the ongoing practice of acts legitimate to that culture, as "performativity". Judith Butler, Gender Trouble: Feminism and the Subversion of Identity (London: Routledge, 1999).

6 'dont que peti Nicolas ele receu et la renvoiier a sa femme et quant elle leu bien cin semaine elle le brula', 2 February 1570, Conseil des Troubles (hereafter CdT), 96: doc. 8r, AGR.

7 'Soit donne à Martin du Val jonne filz demourant a Londres a la maison du filz Terroeuve', Valenciennes, 1 February 1570, CdT, 96: doc. 36v, AGR.

8 'Soit donne a jacque gelle pour adrecer a mary orman demoran en la ville de Londre', 2 February 1570, CdT, 96: doc. 77v, AGR.

9 'A mon oncle pierre gruelz demourant ou quil soit', 2 February 1570, CdT, 96: doc. $4 \mathrm{r}$, AGR.

10 'Je suis a Jan', 10 February 1570, CdT, 96: doc. 89v, AGR.

11 "Interrogations, Saint-Omer, 28 February to 9 March 1570," CdT, 91: docs. 13944v, AGR, quoted in Verheyden, "Correspondance," 226.

12 'il ne scoit ce que c'est d'ung calviniste, ny de mesme d'ung papiste', "Interrogations, Saint-Omer," quoted in Verheyden, "Correspondance," 225-26.

13 Lille, 8 February 1570, CdT, 96: doc. 58r-59r, AGR.

14 Twenty-five of seventy-nine letter-writers (one jointly by a man and woman); twelve of seventy-nine recipients (two jointly directed to men and women).

156 January 1570, CdT, 96: doc. 38r, AGR.

1620 February 1570, CdT, 96: doc. 88r, AGR. 
17 'Item, deux aulnes demye de toille bleuwe. Item, quattre chemises d'ung petit garson. Item, deux chemises de quelque fillette. Item, trois chemises d'homme. Ung Bonnet. Deux pains d'espiches. Deux frommaiges. Des esceulles de confiture. Deux aulnes de toille blanche'. "Interrogations, Saint-Omer," quoted in Verheyden, "Correspondance," 223.

18 'Sachies que ma seur Jacquelinne se recommande de bon coeur a piere le gay', CdT, 96: doc. 31r, AGR.

19 'Ende weet noch dat ic daneels wijf ghesproken hebbe en zy doen u zeer groeten en daneel was naer yper en kalleken haer zuster was noch al fraey en frans ooc', CdT, 96: doc. 22v, AGR.

20 'iay ouir dire a Jan haudoux que Jaquet Rousel luy avoit dict', 20 February 1570, CdT, 96: doc. 88r, AGR.

21 'Louange a Dieu', Hennette to her husband Antoine Renier, n.d., CdT, 96: doc. 41r, AGR; 'Salut par Jésus-Christ', the daughter of Willame le Roy, 20 February 1570, CdT, 96: doc. 88r, AGR.

22 'psalm 46: God es mynen toevlucht an den tyt des druckx', 25 February 1570, CdT, 96: doc. 17r, AGR.

23 Victor Kirstelot to De Conick, 5 February 1570, CdT, 96: doc. 28r, AGR; Gillis vanden Keere to his brother-in-law Jan de Keyzere, 14 February 1570, CdT, 96: doc. 30r, AGR.

24 'al ons bemynde broeders en susters so biddet voor ons alle te saemen dat my moeghen commen alle te saemen met Cristus in syn gloerie al daer wy verhopen te commen met Gods graessye hier', 'de alle broeders die in de heere syn', CdT, 96: doc. $28 \mathrm{v}$, AGR.

25 'Saisies comment que le seigneur dieu a appelle votre mere et la retiré hors de chey vale de misere et partan il ne fault point prendre dennuy de che quil play au seigneur car comme nous disons tous les jours que sa volonte soit faicte et partans puis que che est sa volonte il ne nous en doibt point desplaire elle est bien heuruge car nous navons que paine en seste valee de misere et partans tant que le seigneur dieu nous aura tous aupres de soit et nous aura tire hors de val de misere nous ne povont estre a repos', Armentières, 10 February 1570, CdT, 96: docs. 53r-v, AGR.

26 Costas Gaganakis, "Stairway to Heaven: Calvinist Grief and Redemption in the French Wars of Religion," Historein 8 (2008): 102-7.

27 Valenciennes, 3 February 1570, CdT, 96: doc. 33r, AGR.

28 'aux vrais crestien en che monde', CdT, 96: doc. 31r, AGR.

29 'et loenge a dieu jusques nous a donne nourriture et maulgre nos ennemis nous a faict reposer au parcs herbeux et conduict du long des eaux coies par quy nous avons esperance que en la fin de nos jours que aurons joisance du salut quy nous est acquis par Jesuchrist', 16 February 1570, CdT, 96: doc. 39r, AGR.

30 Twenty-four of seventy-nine letters. 'gheschreven met zeere grooten haesten', Frans Baeke to Willem and Pieter van der Schoore and Frans de Berre, 18 February 1570; 'a cause que le messaiger estoit haste', Justinne Ploiart to her brother Guillame le Myeulx, Tournai, 3 February 1570, CdT, 96: fols. 22v and 44v, AGR.

31 'je pleure mainte fois la sepmaine', 'maintenant je nay personne et il me semble tousjours que je ne vous voiray james plus ny mes deux fille ne vos enfans', 3 February 1570, CdT, 96: doc. 42r, AGR.

32 'je y vouldroye bien estre car je vous promet que le cops est ychy mes mon coeur est aupres de vous bien souvent', Lannoy, 3 February 1570, CdT, 96: doc. 64r, AGR.

33 'touchant vre pere et vre mere ils vous prient tresaffectueusement que vous leur renvoiez de voz nouvelle le plus briefvement quil vous sera possible car daultant quil nont nulle nouvelle de vous Ilz leur semble avoir que vous este mort parquoy tout leur desir est que doner de voz nouvelle pour scavoir de vre estat et comment il vous est en cela faisant vous leur donnerez joie et liesse', CdT, 96: doc. 36r, AGR. 
34 'puis quy a pleu a dieu que nous soions eslongie deu leun lautre il neu nous fait pouin prouque oublier leun lautre de ceur ... il nes jour quen mon ceur ne pleure je prie dieu quy vous veille toujour donne bonne pascience', CdT, 96: doc. 53r, AGR.

35 This is a pattern that can also be observed in the correspondence of other communities in exile. See Broomhall, "Tears on Silk: Cross-Cultural Emotional Performances Among Japanese-Born Christians in Seventeenth-Century Batavia," Pakistan Journal of Historical Studies 1, no.1 (2016): 18-42.

36 'depuis leur et le iours que vous et en vois, son oeil na poinct este secq et tousiours pleure prian Dieu quy vouus veille retourner envers luy et nous tous', 1 February 1570, CdT, 96: doc. 6r, AGR.

37 'vostre fille annette et marie demandent tousiours quant leur pere viendra vostre fille marie dict que vous ne scavez venir et que vous avez mal a voz pieds', 1 February 1570, CdT, 96: doc. 37r, AGR.

38 'Je suis forte esbahie comment vous naves point aussy tot recry une lettres que de necrire sus la lettres de Jan Desmadry', CdT, 96: doc. 41r, AGR.

39 'Et ie menmerveil bien coment ie not nulle nouvelle de luy il en ia pluseur quy rescript bien il me semble sil avoit volunte de rescrire il trouveroit bien pour renvoyet une lestre sy luy plaisoit', n.d., CdT, 96: doc. 84r, AGR.

40 'Je suis fort esmerveillies que a passa deulx ans je nay nulles nouvelles de vous me donnant de merveille/je ne scay sy este courouche contre moy ou non que vous ne mescrives point Sil vous a convenu departier arriere de moy ce ne a este par moy et en suis bien mary Je suis de nuict en grande paine que nay nulles nouvelles de vous combien que je vous ay rescript par plusieurs fois', Valenciennes, 3 February 1570, CdT, 96: doc. 35r, AGR.

41 'ceste present servira pour vous avertir que je suis bien emervielies comment je nay nulle nouvelle de vous car je vous ay envoies plusieur lestre de puis quatre mois et je nay eu nulle reponse de vous dont je ne pensoie point que fusies si ingra de ne point recrir dont je vous prie que faict tout devoir de menvoyer largent que me deves a cauge de marchandige que je vous ay vendu et livre a mon frere et a vous', 4 January 1570, CdT, 96: doc. 90r, AGR.

42 'pour vous advertir comment que marinne ne a plus nulles revenuees cest pourtant que le roy a entendu que les femmes assistoyent leurs hommes/par le moyen de quoy/il a pleut a sa $\mathrm{M}^{\mathrm{e}}$ de tout confisquier les biens/en gnael', 1570, CdT, 96: doc. 8r, AGR.

43 'que je puis estre a mes quatre enfant bon pere et bonne mere', CdT, 96: doc. 84r, AGR.

44 'nous somme a cest heur 7 pouvre enfant sa mere', 'Et est ma seur katelin sans mere', CdT, 96: doc. 3r,v, AGR.

45 'Mon mary je voudroy bien que vous fuschie resider en une ville pour y aller aussi avec vous jay du mal bauco de gainier ma vie je nay point dasitens de person', n.d., CdT, 96: doc. 61r, AGR.

46 'mais largen que mavye adrese je ne laray point ... Jen ay gran disette et pour le presen je nay point ... a gaigne', 'je ne saroye cy nullement gaigne mes depen et vous pry que me le mande le plus brief que poves', 27 January 1570, CdT, 96: doc. 26r, AGR.

47 'et sy nay Je jamais recus de vous nulle response ce samble a voir unne moquerie car nicaise vous poves bien penser que Je nay point les mille escus ... vous estes Cause que ma fille a refuses plusieurs bon mariage car se il y fut venus quelque bon mary voire ung princh il neut point estes posible de le marier car la guisse est telle que on ne demande point les fille pour leur savoir mais pour leur argent', 30 January 1570, CdT, 96: doc. 43r, AGR.

48 See Broomhall, "From France to England."

49 'Je vous prie de tenire la main a vre filz Jehan de luy faire aprendre le latin a bien escripre le chifre et puis apres de le maitre pour aprendre les langaige car il est en poin/fait quy ne pert poin son tamp', 2 February 1570, CdT, 96: doc. 32r, AGR. 
50 'gaingnies a grant labeur ne soit inutillement dissipe', 9 February 1570, CdT, 96: doc. 66r, AGR.

51 Philip Grace, Affectionate Authorities: Fathers and Fatherly Roles in Late Medieval Basel (Farnham: Ashgate, 2015), 9 and 44.

52 See Broomhall, "Authority in the French Church."

53 'nous somme fort tourmentez de souldat espanol', CdT, 96: doc. 33r, AGR.

54 CdT, 96: docs. 58r-59r, AGR.

55 CdT, 96: doc. 30v, AGR.

56 'nous ne savon rien recevoir partant nous soufron beaucop de malle et des oultre ausy parquoy nous ne pouvon aider leun lautre partant nous ne somme point seulle en dangere', Lot to her husband Tomas le Clercque, 2 February 1570, CdT, 96: doc. 57r, AGR.

57 'car se je vend le Roy le voroit prendre', CdT, 96: doc. 89r, AGR.

58 'de vous rescripre des ravissement de leurs pilleries et dangier de nos persones seroit long a escripre', CdT, 96: doc. 39r, AGR.

59 'Touchant de Lambert il est mort par lespee', CdT, 96: doc. 38r, AGR.

60 'je espere avecq le tamp que les prinches se trouveront dacort ensamble par ou le peuple pora ettre en paix nous prion tous a dieu quy le maiche dacort', CdT, 96: doc. 32r, AGR.

61 ' $t$ verbodt hebben hooren preken en die van de consistoorie waeren dootmen noch hier en daer eene', CdT, 96: doc. 30v, AGR.

62 'prendes corages le tout changeras ung bien si plet a Dieu', 15 February 1570, CdT, 96: doc. 9r, AGR.

63 'nous serieme fors joieus ce vous revenies; ...tant pour le pais on il est en paist pour leure ce vous vole revenir pour juer ou pour demore vous cere le bien venus', 11 November 1570, CdT, 96: doc. 70r, AGR.

64 'ne veillez point prendre merancolie car pour le present on ne die rien en Vallenchiennes ... il est bon vray que on a conffisquiez les biens daulcun de ceulx qui sont bany ou crie/mais on ne parolle/de rien pour lheure et a la mienne voulente que fusiez aupres de vostre femme et voz enffans car vous seriez le paisible aussy bien que les aultres quy reviennent journellement', CdT, 96: doc. 37r, AGR.

65 'je vous vodre bien consilies le retour suivi ne craiendes riens car le afaier ne sont de sy movemanties a faier com om vous dit', 'vous series en osi grand seurrete la ou je vous dis que la ou vous est a present', 7 February 1570, CdT, 96: doc. 11r, AGR.

66 'Je suis bien marie que vous este alle sy loing du pais il ny a des aultres que vous cognoissies bien qui sont comme nous quil ne sont point sy loing et se font bien leur chose', CdT, 96: doc. 64v, AGR.

\section{Bibliography}

Backhouse, Marcel F., The Flemish and Walloon Communities at Sandwich during the Reign of Elizabeth I (1561-1603). Brussels: Koninklijke Academie voor Wetenschappen, Letteren en Schone Kunsten, 1995.

Barad, Karen. "Posthuman Performativity: Towards an Understanding of How Matter Comes to Matter," Signs 28, no.3 (2003): 801-831.

Bennett, Jane. Vibrant Matter: A Political Ecology of Things. Durham, NC: Duke University Press, 2010.

Broomhall, Susan. "Authority in the French Church in Later Sixteenth-Century London." In Authority, Gender and Emotions in Late Medieval and Early Modern England, edited by Susan Broomhall, 131-149. Basingstoke: Palgrave, 2015.

Broomhall, Susan. "From France to England: Huguenot Charity in London." In Experiences of Charity, 1250-1650: Revisiting Religious Motivations in the Charitable Endeavour, edited by Anne M. Scott, 191-212. Farnham: Ashgate, 2015. 
Broomhall, Susan. "Tears on Silk: Cross-Cultural Emotional Performances among Japanese-Born Christians in Seventeenth-Century Batavia," Pakistan Journal of Historical Studies 1, no.1 (2016): 18-42.

Butler, Judith. Gender Trouble: Feminism and the Subversion of Identity. London: Routledge, 1999.

Coole, Diana and Samantha Frost, eds. New Materialisms: Ontology, Agency, and Politic. Durham: Duke University Press, 2010.

Gaganakis, Costas. "Stairway to Heaven: Calvinist Grief and Redemption in the French Wars of Religion," Historein 8 (2008): 102-107.

Goose, Nigel and Liên Luu, eds. Immigrants in Tudor and Early Stuart England. Brighton: Sussex Academic Press, 2005.

Grace, Philip. Affectionate Authorities: Fathers and Fatherly Roles in Late Medieval Basel. Farnham: Ashgate, 2015.

Grell, Ole Peter. Dutch Calvinists in Early Stuart London: The Dutch Church in Austin Friars, 1603-1642. Leiden: Brill, 1989.

Grell, Ole Peter. Calvinist Exiles in Tudor and Stuart England. Brookfield VT; Aldershot: Scolar Press; Ashgate Publishing Company, 1996.

Gwynn, Robin D. Huguenot Heritage: The History and Contribution of the Huguenots in Britain. 1995; reprint Brighton: Sussex Academic Press, 2001.

Latour, Bruno. Reassembling the Social: An Introduction to Actor-Network Theory. Oxford: Oxford University Press, 2005.

Miller, Daniel, ed. Materiality. Durham, NC: Duke University Press, 2005.

Pettegree, Andrew. Foreign Protestant Communities in Sixteenth-Century London. Oxford: Oxford University Press, 1986.

Spicer, Andrew. The French-Speaking Reformed Community and Their Church in Southampton, 1567-C.1620. London: Huguenot Society, 1997.

Verheyden, A.L.E., "Une correspondence inédite adressée par des familles protestantes des Pays-Bas à leurs coreligionaires d'Angleterre (11 novembre 1569-25 février 1570)," Bulletin de la Commission royale d'histoire 120 (1955): 95-257.

Vigne, Randolph and Graham C. Gibbs, eds. The Strangers' Progress: Integration and Disintegration of the Huguenot and Walloon Refugee Community, 1567-1889: Essays in Memory of Irene Scouloudi. London: Huguenot Society, 1995. 